\title{
KEBIJAKAN INDONESIA MENOLAK MENGGUNAKAN MEKANISME AATHP JOINT EMERGENCY RESPONSE DALAM MENGATASI KEBAKARAN HUTAN DAN LAHAN 2015
}

\author{
Luerdi dan Melly Wulandari
}

Printed version available at: https://ojs.unikom.ac.id/index.php/jipsi/article/view/5252

\section{Citation as:}

Luerdi, L. \& Wulandari, M. (2021). Kebijakan Indonesia Menolak Menggunakan Mekanisme AATHP Joint Emergency Response dalam Mengatasi Kebakaran Hutan dan Lahan 2015. JIPSi: Jurnal Ilmu Politik dan Komunikasi, 11(2), 48-78. 
KEBIJAKAN INDONESIA MENOLAK MENGGUNAKAN MEKANISME AATHP JOINT EMERGENCY RESPONSE DALAM MENGATASI KEBAKARAN HUTAN DAN LAHAN 2015

Penulis: Luerdi \& Melly Wulandari

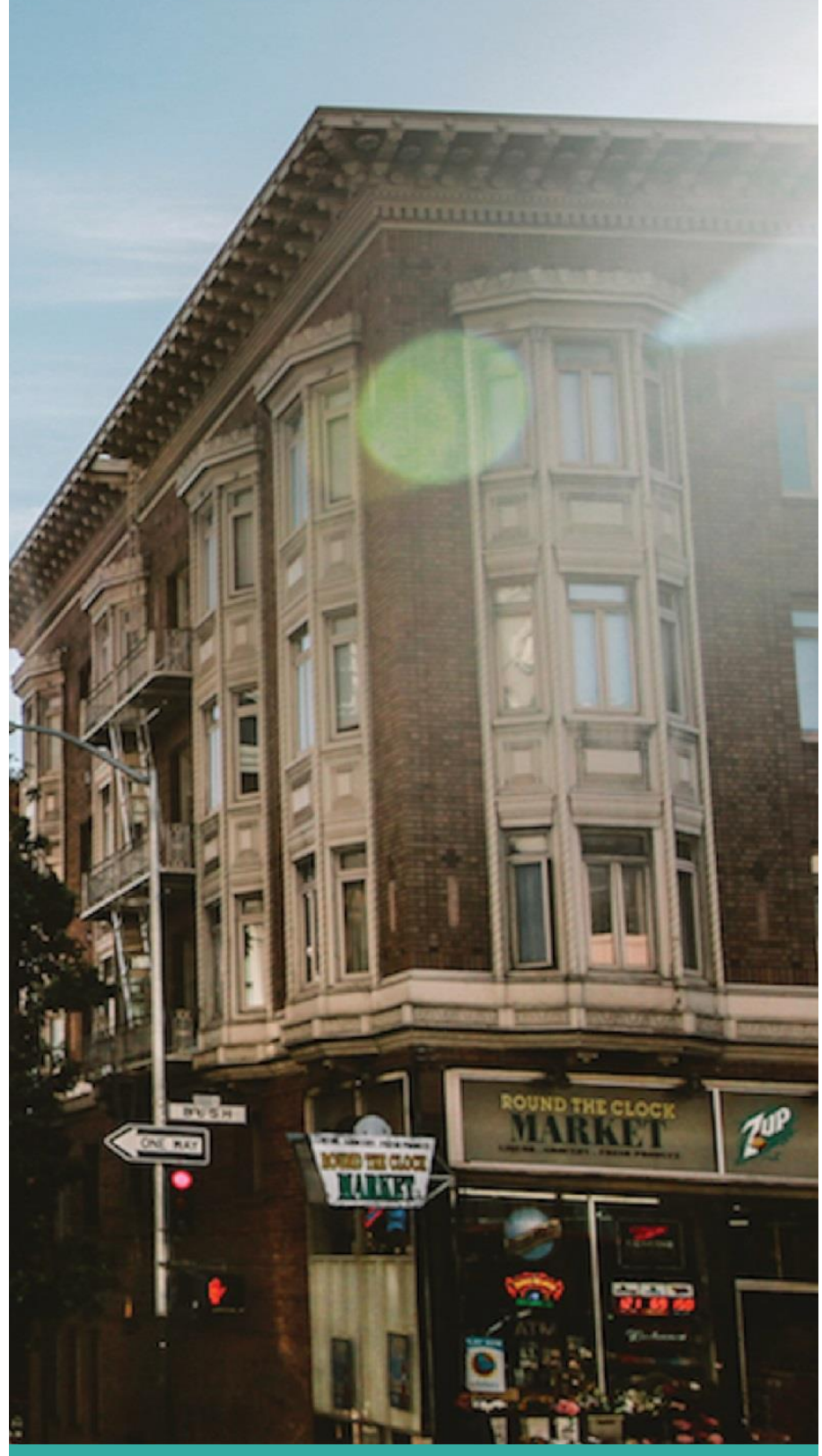

Laporan Penelitian, 2020

Prodi Ilmu Hubungan Internasional Universitas Abdurrab 


\title{
KEBIJAKAN INDONESIA MENOLAK MENGGUNAKAN MEKANISME AATHP JOINT EMERGENCY RESPONSE DALAM MENGATASI KEBAKARAN HUTAN DAN LAHAN 2015
}

\author{
Luerdi $^{1}$, Melly Wulandari ${ }^{2}$ \\ 1,2Prodi Ilmu Hubungan Internasional, Universitas Abdurrab, Indonesia
}

Email: luerdi@univrab.ac.id

\begin{abstract}
This paper aims to explain Indonesia's rejection to resolve its 2015 forest and land fire disaster under the mechanism of Joint Emergency Response provided in the ASEAN Agreement on Transboundary Haze Pollution. The haze caused by forest and land fires in Indonesia raised threats to not only itself but also states in the region of Southeast Asia. As it was declared as a regional problem, ASEAN then responded by creating a common framework called the ASEAN Agreement on Transboundary Haze Pollution in 2002 and Indonesia was the last ratifying the agreement in 2014; more than a decade after its inception. Indonesia, however, refused to pick the AATHP Joint Emergency Response to tackle the 2015 disaster within its territorry despite its most serious recurring disaster since 1997. This research applied the qualitative method with a causal correlation analysis. The research applied Charles $O$. Lerche and Abdul A. Said's national interest theory. The research found that Indonesia's rejection was driven by its national interests such as image, economy and politics which were much more important than others. Instead, Indonesia preferred the domestic efforts and bilateral cooperation to respond to it. The paper argues that the Southeast Asian regional institution is not able to offer incentives overtaking states' domestic-oriented national interests.
\end{abstract}

Keywords: Forest and land fire, haze, Joint Emergency Response, national interest.

\begin{abstract}
Abstrak
Tulisan ini bertujuan untuk menjelaskan penolakan Indonesia dalam mengatasi bencana kebakaran hutan dan lahan yang terjadi pada 2015 dengan mekanisme Joint Emergency Response yang terdapat pada ASEAN Agreement on Transboundary Haze Pollution. Kabut asap akibat kebakaran hutan dan lahan di Indonesia telah menyebabkan ancaman tidak hanya bagi Indonesia sendiri tapi juga bagi negara-negara di kawasan Asia Tenggara. Ketika masalah tersebut menjadi isu regional, ASEAN kemudian merespon dengan membuat satu kerangka kerja yang disebut ASEAN Agreement on Transboundary Haze Pollution pada 2002 dan Indonesia merupakan pihak yang paling akhir meratifikasi perjanjian tersebut. Namun, Indonesia menolak untuk menerapkan mekanisme Joint Emergency Response dalam mengatasi bencana kebakaran hutan dan lahan 2015 di wilayahnya walaupun bencana tersebut merupakan yang terparah sejak 1997. Penelitian ini menggunakan metode kualitatif dengan analisis korelatif kausal. Penelitian ini menggunakan teori kepentingan nasional oleh Charles O. Lerche dan Abdul A. Said. Temuan penelitian ini adalah kepentingan nasional seperti citra, ekonomi dan politik mendorong Indonesia untuk menolak menggunakan mekanisme tersebut dalam mengatasi bencana kebakaran hutan dan lahan 2015. Sebaliknya, Indonesia lebih memilih menerapkan upayaupaya domestik dan kerjasama bilateral dalam merespon bencana tersebut. Tulisan ini memiliki argumen bahwa institusi regional Asia Tenggara belum mampu memberikan insentif yang melebihi kepentingan nasional negara yang berorientasi domestik.
\end{abstract}

Kata kunci: Kebakaran hutan dan lahan; kabut asap; Joint Emergency Response; kepentingan nasional.

\section{Pendahuluan}

Indonesia merupakan negara di kawasan Asia Tenggara di mana kebakaran hutan dan lahan (karhutla) telah sering terjadi sejak 1970-an (Alfajri, Setiawan \&
Wahyudi, 2019). Laporan World Wild Fund (WWF) menyebutkan karhutla menjadi salah satu kontributor utama dalam penyusutan sejumlah 1,1 juta ha atau 2 persen hutan di Indonesia setiap tahunnya (Sari \& Nirmala, 2019). Karhutla 
tidak hanya menjadi ancaman bagi Indonesia, tetapi juga berdampak pada negara-negara tetangga khususnya Singapura dan Malaysia. Kedua negara tersebut telah sering menyampaikan keberatan berkaitan dengan dampak ekonomi dan kesehatan warga negara mereka. Tensi politik antara Indonesia dan negara ASEAN lainnya juga sering terjadi. Misalnya pada tahun 2013, Menkokesra Agung Laksono menyatakan Singapura 'terlalu kekanak-kanakan' dan 'suka mengeluh', namun akhirnya Presiden SBY menyatakan permintaan maaf kepada Singapura dan Malaysia atas bencana kabut asap yang disebabkan oleh karhutla di Indonesia (Gunawan, 2014).

Kabut asap akibat karhutla telah membawa Indonesia dan negara-negara di kawasan untuk membicarakan solusi dalam wadah ASEAN. Pada 2002, negaranegara anggota ASEAN berkumpul untuk menciptakan satu kerangka kerja demi mengatasi kabut asap di kawasan yang dikenal dengan Perjanjian ASEAN tentang Polusi Kabut Asap Lintas Batas (ASEAN Agreement on Transboundary Haze Pollution - AATHP). Kerangka tersebut dirancang untuk mengatasi kabut asap yang memuat "monitoring and assessment, prevention, preparedness, national and joint emergency response, procedures for deployment of people, materials and equipment across borders, technical cooperation and scientific research" (Purwendah \& Mangku, 2018; AATHP, n.d). Adapun tujuan dari AATHP adalah seperti yang tertulis pada pasal 3:

"The objective of this Agreement is to prevent and monitor transboundary haze pollution as a result of land and/or forest fires which should be mitigated, through concerted national efforts and intensified regional and international co-operation. This should be pursued in the overall context of sustainable development and in accordance with the provisions of this Agreement" (AATHP, n.d).

Dari pasal di atas, dapat diketahui bahwa tujuan AATHP adalah untuk mencegah dan memonitor polusi kabut asap lintas batas yang disebabkan oleh karhutla yang seharusnya dimitigasi. Pasal tersebut juga menekankan bahwa upaya mengatasi karhutla tetap mengutamakan upaya pemerintahan nasional negara yang bersangkutan, kemudian diintensifkan dengan kerjasama regional dan internasional.

Malaysia adalah negara pertama yang berkomitmen terhadap AATHP dengan melakukan ratifikasi pada tahun yang sama ketika perjanjian tersebut disepakati. Langkah Malaysia kemudian diikuti oleh negara-negara ASEAN lainnya. Namun, AATHP yang mulai berlaku pada 2003 belum dianggap efektif karena Indonesia yang hutan dan lahannya sering mengalami kebakaran belum meratifikasi perjanjian tersebut selama 12 tahun sejak disepakati. Selama itu pula Indonesia berdalih bahwa kerangka regional tersebut tidak akan berfungsi dengan baik untuk mengatasi kabut asap karena perdebatan diantara negara-negara anggota.

Keengganan Indonesia untuk meratifikasi AATHP bertentangan dengan keinginan ASEAN untuk mewujudkan kawasan yang bersih dan hijau yang merujuk pada pembangunan berkelanjutan dan ramah lingkungan. Sedangkan, kebijakan regional ASEAN pada dasarnya bertujuan untuk memelihara eksistensi organisasi dan kepercayaan negara-negara anggota. Untuk mewujudkan kerjasama regional tersebut, ASEAN telah membujuk Indonesia agar melakukan ratifikasi karena AATHP tidak hanya bermanfaat bagi kawasan secara keseluruhan, tapi juga dapat menjadi solusi bagi masalah karhutla di wilayah Indonesia. Bila saja Indonesia telah meratifikasi AATHP, maka karhutla tidak lagi menjadi tanggungjawab Indonesia semata, tapi seluruh anggota 
ASEAN. Dengan demikian, ASEAN akan lebih efektif mengelola polusi kabut asap lintas batas (Jerger Jr, 2014). Indonesia akhirnya meratifikasi AATHP pada 14 Oktober 2014 yang dituangkan dalam Undang-Undang Nomor 26 Tahun 2014.

Namun, paska ratifikasi masalah karhutla di Indonesia semakin rumit, tepatnya pada 2015 ketika bencana tersebut kembali terjadi dan merupakan yang terlama dan terparah dalam sejarah bencana kerhutla Indonesia setelah peristiwa karhutla 1997 (Burki, 2017). Mekanisme multilateral yang tersedia pada AATHP berupa Joint Emergency Response (JER) pun tidak digunakan oleh Indonesia.

Beberapa literatur telah mengkaji faktor penyebab bencana karhutla dan kabut asap. Kajian sekuritisasi isu-isu lingkungan di Asia Tenggara telah dilakukan oleh Apriwan (2012). Namun, ketidakberhasilan upaya sekurititasi kabut asap oleh pemerintah Indonesia menjadi penyebab bencana karhutla dan kabut asap terjadi berulang-ulang (Edwards \& Heiduk, 2015). Desentralisasi dan distribusi power dalam rezim politik berkontribusi terhadap ketidakberhasilan sekuritasi tersebut (Edwards \& Heiduk, 2015). Ketidakoptimalan pemerintah Indonesia menjadikan bencana sebagai instrumen diplomasi juga menjadi penyebab bencana karhutla (Fathun, 2016).

Sementara Anggarwal dan Chow (2010) dan Varkkey (2012a) melihat permasalahan kabut asap di tingkat regional. ASEAN way menjadi penghambat kerjasama lingkungan di kawasan (Anggarwal \& Chow, 2010) dan telah mampu menjaga kepentingan elit politik dan ekonomi melalui berbagai inisiatif yang malahan menjadi penghambat mitigasi kabut asap (Varkkey, 2012a). Norma ini lah yang menjadi constraint Singapura sebagai korban dalam berinteraksi dengan Indonesia dan ASEAN terkait karhutla dan kabut asap (Varkkey, 2011). Melihat jauh ke belakang,
Dauvergne (1998) juga telah mengkaji ekonomi politik bencana karhutla 1997.

Beberapa literatur secara khusus juga telah mengkaji sikap Indonesia terhadap AATHP. Pada awalnya Indonesia menolak meratifikasi AATHP disebabkan oleh faktor pembangunan ekonomi, kelompok kepentingan dan persaingan antar elit (Febriyani, 2019) dan prinsip non-interference yang melekat pada ASEAN (Ahmadi, 2012). Hurley dan Lee (2020) mengkaji penundaan tersebut dengan melihat proses ratifikasi oleh DPR. Institusi tersebut baru melihat dukungan aktor-aktor domestik dan tekanan internasional yang kuat pada 2010-an sebagai alasan ratifikasi AATHP (Hurley \& Lee, 2020).

Di saat kritik terhadap AATHP, ASEAN masih dianggap sebagai aktor penting di kawasan. Perubahan sikap Indonesia yang ditandai dengan ratifikasi AATHP tidak terlepas dari peran independen ASEAN sebagai aktor yang mampu menekan Indonesia (Suartini et al., 2018). Namun, Shidiq (2016) melihat perubahan sikap tersebut sebagai bentuk pengaruh tekanan kelompok masyarakat dalam menuntut pertanggungjawaban negara. Permasalahan paska ratifikasi oleh Indonesia telah dikaji oleh Heilmann (2015) dan Ghani et al (2017). Sifat nonbinding AATHP ternyata masih menjadi masalah utama paska ratifikasi oleh Indonesia (Heilmann, 2015; Ghani et al., 2017). Varkkey (2017) bahkan melihat kebijakan domestik Indonesia di era Presiden Joko Widodo dalam penanganan masalah karhutla berimplikasi pada peminggiran peran ASEAN dan negaranegara anggotanya. Walaupun demikian, Yani dan Robertua (2018) melihat ratifikasi AATHP oleh Indonesia sebagai salah satu fondasi pemerintahan lingkungan regional di Asia Tenggara dalam pandangan English School.

Kajian bencana karhutla dan kabut asap regional di tingkat daerah, seperti Riau telah dilakukan oleh beberapa peneliti. Kebijakan pemerintah propinsi 
Riau dalam mewujudkan tujuan AATHP tidak terlepas dari dukungan dan tuntutan dari aktor lokal. Namun, tuntutan yang berasal dari kelompok masyarakat sipil lokal tidak memberikan perubahan signifikan terhadap kebijakan pemerintah Riau dalam masalah karhutla dan kabut asap (Alfajri, Setiawan \& Wahyudi, 2020). Walaupun berbagai kebijakan telah dibuat oleh pemerintah daerah beberapa tahun belakangan, implementasi di lapangan yang lemah dan rumit serta perilaku elit dan publik Riau yang abai terhadap bencana tetap memberikan pekerjaan rumah paska $A S E A N$ 's haze-free roadmap 2020 yang akan berdampak pada diplomasi Indonesia (Alfajri, Setiawan \& Wahyudi, 2021). Kajian-kajian tersebut mencoba menempatkan aktor-aktor lokal 'penting' dalam isu kawasan, selain aktor nasional dan regional.

Kajian-kajian terdahulu di atas mengkonfirmasi bahwa Indonesia merupakan aktor utama dalam permasalahan kabut asap lintas batas di Asia Tenggara. Bencana kabut asap akibat karhutla di Indonesia dan AATHP merupakan isu penting dalam hubungan internasional di kawasan baik sebelum ataupun sesudah ratifikasi oleh Indonesia. AATHP menjadi harapan bagi ASEAN dan negara-negara anggota untuk menciptakan kawasan bebas kabut asap. Di sisi lain, AATHP juga menunjukkan ketidakefektifan dalam mewujudkan agenda tersebut. Namun, kajian-kajian tersebut tidak memberikan penjelasan tentang preferensi Indonesia menolak bekerjasama secara multilateral di bawah payung AATHP, sedangkan Indonesia telah meratifikasi perjanjian tersebut pada 2014.

Kajian-kajian terdahulu juga tidak secara tegas menyebutkan posisi JER yang ada pada AATHP. Penelitian ini menegaskan bahwa Indonesia sebenarnya memiliki pilihan untuk berkerjasama secara kolektif dalam menangani bencana karhutla dan kabut asap 2015 melalui mekanisme tersebut. Penelitian ini mencoba menganalisa kebijakan Indonesia untuk menolak menggunakan mekanisme JER yang ada pada AATHP dalam merespon bencana karhutla 2015 dengan melihat variabel kepentingan nasional.

Kajian Varkkey (2012a) telah menyentuh kepentingan nasional. Kajian tersebut mampu menjelaskan hubungan tradisional antara elit politik dan ekonomi dibalik rasionalisasi kepentingan nasional ketika sektor industri kelapa sawit menjadi semakin penting (Varkkey, 2012a). Namun, kajian tersebut tidak secara khusus menjelaskan kepentingan nasional Indonesia dan kepentingan tersebut dianalisis sebelum ratifikasi AATHP oleh Indonesia. Selain itu, kajian tersebut hanya menyentuh dimensi kepentingan ekonomi negara. Sedangkan penelitian ini melihat kepentingan nasional Indonesia yang lebih luas meliputi citra, ekonomi dan politik paska ratifikasi AATHP.

Tulisan ini akan menjawab pertanyaan: "Mengapa Indonesia menolak untuk menyelesaikan bencana karhutla 2015 dengan mekanisme JER yang terdapat dalam AATHP?" Tulisan ini akan berkontribusi dalam memahami perilaku Indonesia ditengah-tengah ekspektasi aktor-aktor regional terhadap kawasan bebas kabut asap serta bargaining position Indonesia terhadap aktor-aktor tersebut melalui AATHP.

\section{Kerangka Teoritis}

Kajian tentang kepentingan nasional sering disamakan dengan kajian tentang negara pada politik internasional. Politik luar negeri satu negara merefleksikan kebijakan nasionalnya, sedangkan kebijakan nasional tersebut tergantung pada kepentingan nasional. Untuk memahami perilaku Indonesia dalam merespon bencana karhutla 2015, penelitian ini menggunkan teori kepentingan nasional yang dikembangkan oleh Charles O. Lerche dan Abdul A. Said. Teori ini menekankan pada konsep objective dari kepentingan nasional dalam 
proposisi "an objective flows from the application of national interest to the generalized situation in which policy is being made" (Lerche \& Said, 1995).

Intended action merupakan respon negara dalam wujud kebijakan yang selalu diarahkan untuk memperoleh tujuan tertentu yang berasal dari kepentingan nasional. Kepentingan nasional tetap penting untuk menjelaskan, mendeskripsikan, meramalkan dan mempreskripsikan kebijakan dalam panggung politik internasional. Seperti yang teori ini argumentasikan, kebijakan nasional tidak dapat dipisahkan dari kepentingan nasional karena political objective dari negara adalah untuk mengejar dan mempertahankan kepentingan nasional (Lerche \& Said, 1995). Sedangkan kepentingan nasional itu sendiri tidaklah berwujud tunggal, seperti yang diungkapkan Lerche dan Said (1995):

"Self preservation (on the collective entity of the state and its human and territorial manifestation), security, well being prestige, power, the promotion and or protection of ideology or any other as defined synthesized and giving form by the decision makers of the country is considered as the general, long term, in countinuing purpose which the state, the nation and the government all see themselves as serving".

Bentuk kepentingan nasional dapat beragam seperti self-preservation di mana negara dan orang di dalamnya dapat bertahan hidup, keamanan, prestise, promosi dan perlindungan ideologi dan bentuk lainnya. Tujuan dari kepentingan nasional akan dipertahankan dan dikejar secara konsisten oleh pemerintah negara atau pembuat kebijakan untuk keberlanjutan atau eksistensi negara.

Dalam penelitian ini, Indonesia menolak untuk menggunakan mekanisme
JER yang ada pada AATHP didorong oleh serangkaian kepentingan nasional; yaitu citra (status atau prestise), ekonomi dan politik. Berkaitan dengan kepentingan citra, bila Indonesia meminta bantuan kepada ASEAN, maka keputusan tersebut akan menimbulkan citra bahwa Indonesia secara tidak langsung mengakui ketidakmampuannya dalam mengatasi karhutla yang terjadi di wilayahnya. Kebijakan untuk menerapkan mekanisme JER juga akan menganggu ekonomi nasional. Melalui JER, ASEAN dan negara-negara anggota memiliki potensi melakukan intervensi terhadap ekonomi Indonesia setelah mengakses data strategis nasional berkaitan dengan industri perkebunan dan kehutanan di wilayahnya. Perkebunan kelapa sawit dan hutan tanaman industri telah berkontribusi menjaga stabilitas ekonomi dan menjadi sumber pendapatan (devisa dan nondevisa) bagi Indonesia selain menciptakan lapangan pekerjaan bagi penduduk lokal. Sedangkan untuk pertimbangan politik, Indonesia menginginkan mutual advantage di tengah isu bencana karhutla dan kabut asap, yaitu keinginan agar Singapura mewujudkan perjanjian ekstradisi dengan Indonesia.

Selama proses pembentukan kepentingan nasional, pembuat keputusan harus melihat situasi ketika kebijakan dibuat sehingga objective sejalan dengan kepentingan nasional. Walaupun AATHP didorong oleh keinginan dan komitemen kolektif negara-negara anggota ASEAN untuk mewujudkan kawasan bebas kabut asap, perjanjian tersebut tetap saja berdasarkan prinsip umum ASEAN, yaitu non-interference dan konsensus (Heilmann, 2015). Dengan demikian, ASEAN tidak dapat memaksa satu negara anggota pun untuk menerapkan mekanisme JER walaupun bencana karhutla yang parah terjadi di wilayahnya dan kabut asap menyelimuti langit kawasan. Sebaliknya, hanya bila negara anggota yang bersangkutan secara suka rela menyatakan status darurat nasional, 
kemudian negara tersebut dapat menerapkan mekanisme JER dan bekerjasama dengan negara-negara anggota ASEAN lainnya setelah meminta bantuan kepada ASEAN Centre.

Untuk menjaga kepentingan nasional di atas, Indonesia lebih memilih upaya-upaya nasional atau inisiatif domestik dan kerjasama bilateral dalam mengatasi karhutla 2015. Indonesia mengumumkan kesanggupan untuk mengatasi masalah tersebut dengan sumber daya domestik, tapi juga menyambut dengan selektif bantuan negara-negara lain secara bilateral. Selain itu, Indonesia konsisten menyuarakan ketidakefektifan AATHP sebagai pembenaran untuk tidak mendeklarasikan bencana karhutla 2015 sebagai darurat nasional sehingga tidak ada kewajiban bagi Indonesia untuk meminta bantuan kepada ASEAN dan menerapkan mekanisme JER.

\section{Metode Penelitian}

Penelitian ini menggunakan pendekatan kualitatif dengan analisis korelatif kausal di mana peneliti mencari hubungan sebab akibat dari dua variabel. Kepentingan nasional merupakan variabel independen (unit eksplanasi), sedangkan sikap penolakan merupakan variabel dependen (unit analisa) dalam penelitian ini. Penelitian ini merupakan penelitian kepustakaan di mana data diperoleh dari artikel jurnal, buku, dokumen resmi dan sumber-sumber lainnya yang relevan. Sedangkan data dianalisa dengan menggunkan teknik analisa interaktif Miles-Hubberman yang terdiri dari beberapa tahapan yaitu pengumpulan data, reduksi data, penyajian data dan verifikasi atau pengambilan kesimpulan (Idrus, 2009).

Pada tahap pengumpulan data, peneliti mengumpulkan sebanyak mungkin data yang berkaitan dengan fenomena karhutla yang terjadi di Indonesia dan kabut asap lintas batas serta AATHP. Pada tahap reduksi data, peneliti memilah dan memilih data agar dapat mengajukan pertanyaan kritis sehingga fenomena yang dikaji lebih spesifik. Adapun pertanyaan kritis yang diajukan peneliti adalah seputar respon Indonesia terhadap bencana karhutla 2015 dan penolakan terhadap mekanisme JER yang ada pada AATHP. Pada tahap penyajian data, peneliti menyusun informasi untuk memungkinkan mengambil kesimpulan sementara. Peneliti tetap melakukan pengumpulan dan reduksi data secara bersamaan. Pada tahap verifikasi, kesimpulan mulai terlihat jelas dan kuat setelah peneliti mencari arti, mencatat keteraturan, pola-pola penjelasan, konfigurasi, alur sebab akibat dan proposisi. Adapun kesimpulan (temuan) dalam penelitian ini adalah kepentingan nasional mendorong Indonesia untuk menolak menerapkan mekanisme JER yang terdapat pada AATHP dalam menangani bencana karhutla 2015.

\section{Hasil dan Pembahasan}

\subsection{Situasi Karhutla dan Kabut Asap 2015 dan Mekanisme JER pada AATHP}

Bencana karhutla 2015 telah menyebabkan hilangnya lebih dari 2,6 juta ha lahan dan hutan; angka tersebut seluas 4,5 kali pulau Bali (Glauber et al., 2016) atau berdasarkan laporan Badan Nasional Penanganan Bencana (BNPB) seluas 32 kali propinsi DKI Jakarta (Zulaeha, 2016). Dari 34 propinsi di Indonesia hanya tiga yang bebas dari karhutla ketika itu, yaitu DKI Jakarta, Kepulauan Riau dan Yogyakarta; sedangkan yang terparah sebarannya berada di Sumatera dan Kalimantan (Sipongi, 2015).

Selain menyebabkan 24 anak-anak dan dewasa meninggal dunia (Purnomo et al., 2019), ratusan ribu orang menderita masalah kesehatan dan penutupan sekolahsekolah, World Bank mencatat Indonesia menderita kerugian ekonomi senilai lebih 
dari USD 16 miliar (Glauber et al., 2016). Sedangkan kerugian lingkungan akibat kemusnahan keanekaragaman hayati diperkirakan dapat mencapai USD 295 juta (Gunardi, Masman \& Martono, 2017). Nilai kerugian ekonomi tersebut dua kali lebih besar ketimbang kerugian akibat bencana tsunami Aceh 2004 silam atau setara dengan 1,8 persen GDP Indonesia (Gunawan \& Yogar, 2019). Bebarapa daerah telah mencapai indeks standar pencemaran udara (ISPU) pada level tertinggi yaitu sangat berbahaya seperti Riau, Jambi, Sumsel, Kalsel, Kalteng dan Kalbar (Kementerian Kesehatan RI, 2015).

Kabut asap beracun akibat karhutla 2015 menyelimuti sebagian wilayah Indonesia dan beberapa negara tetangga seperti Singapura, Malaysia, Thailand, Filipina dan Brunei Darussalam selama beberapa minggu. Selama bulan Juni-
Oktober 2015 saja, telah tercatat lebih dari 100 ribu kasus karhutla dan diperkirakan lebih dari 1,7 miliar ton karbon dilepaskan ke atmosfer; angka tersebut setara dengan jumlah yang dihasilkan oleh Brasil selama 1 tahun (BBC Indonesia, 2016). Badan Meteorologi, Klimatologi dan Geofisika (BMKG) bahkan melabeli bencana karhutla dan kabut asap 2015 sebagai sebuah kejahatan luar biasa terhadap kemanusiaan (Tay, Chen \& Yi, 2016). Fenomena El Nino di Asia Tenggara dan luasnya lahan gambut di Indonesia yang terbakar semakin mempersulit upaya untuk mengatasi bencana tersebut. El Nino merupakan fenomena peningkatan temparatur permukaan laut yang menyebabkan tingkat curah hujan menurun, sedangkan intensitas kekeringan meningkat (Ku Yusof et al., 2017).

Gambar 1.

Citra Satelit NASA yang Menunjukan Tutupan Kabut Asap pada 27 September 2015

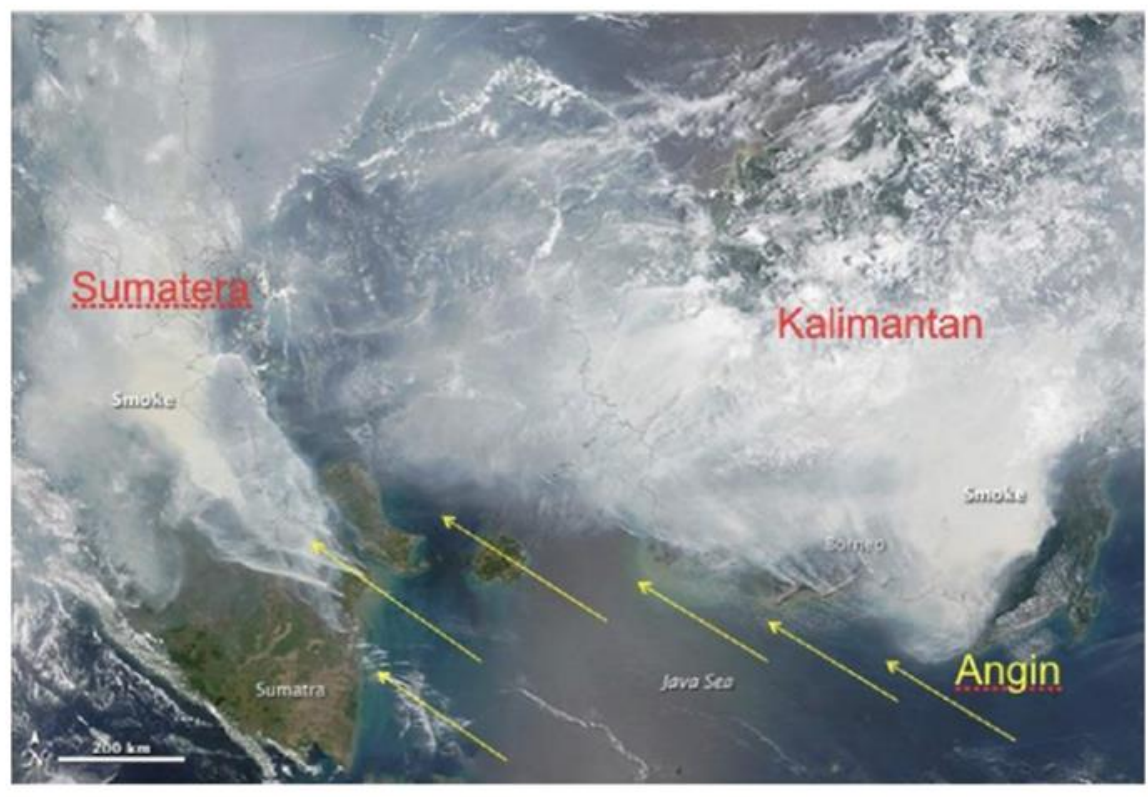

Sumber: (Sarmiasih \& Pratama, 2019)

AATHP terdiri dari 4 bagian dengan 32 pasal dan 1 lampiran. Pada bagian ke-dua tentang monitoring, assessment, prevention and response pasal ke-5 tertulis seperti di bawah ini:
"The ASEAN Centre shall work on the basis that the national authority will act first to put out the fires. When the national authority declares an emergency situation, it may make a request 


\section{to the ASEAN Centre to provide assistance" (AATHP, n.d).}

Dengan melihat pasal di atas dan mempertimbangkan tingkat keparahan bencana, paska ratifikasi oleh Indonesia, ASEAN seharusnya dapat terlibat lebih aktif dan kerjasama multilateral dapat dilaksanakan dalam mengatasi bencana karhutla dan kabut asap 2015 bila saja Indonesia memilih untuk menggunakan mekanisme JER. JER merupakan mekanisme kolektif atau multilateral manajemen penyelesaiakan masalah kabut asap yang disebabkan oleh karhutla di bawah payung ASEAN bila negara anggota tidak mampu menyelesaikan masalah tersebut dengan kebijakan nasional. Namun, Indonesia menolak untuk menggunakan JER seperti yang diharapkan oleh ASEAN dan khususnya Malaysia dan Singapura. Sebaliknya, Indonesia menyatakan masih mampu menyelesaikan karhutla di wilayahnya sehingga tidak menyatakan situasi darurat nasional. Kritik terhadap kelambanan dan ketidakmampuan Indonesia juga datang dari dalam negeri mengingat bencana berlangsung dalam waktu yang cukup lama dan dampak yang begitu luas bagi masyarakat. Karhutla dan kabut asap 2015 hanya berkurang secara signifikan ketika memasuki musim penghujan di akhir Oktober dan berlangsung sepanjang November 2015 (Jakarta Globe, 2015). Sikap penolakan tersebut didorong oleh kepentingan nasional yang ingin dipertahankan oleh Indonesia, berupa kepentingan citra, ekonomi dan politik.

\subsection{Kepentingan Nasional Indonesia}

\subsubsection{Kepentingan Mempertahankan Citra}

Paska ratifikasi AATHP, Indonesia seharusnya dapat mengatasi karhutla 2015 dengan mekanisme JER yang ada pada AATHP mengingat tingkat keparahan bencana. Namun, Indonesia enggan meminta bantuan ASEAN bahkan sering menolak bantuan yang ditawarkan individual negara-negara ASEAN lainnya dengan alasan paket bantuan yang diajukan tidak sesuai dengan apa yang dibutuhkan.

Walaupun sering ditolak, negaranegara tersebut sering pula mempertanyakan kebutuhan seperti apa yang diinginkan Indonesia agar bencana karhutla dan kabut asap dapat diatasi dengan cepat. Bila Indonesia meminta bantuan kepada ASEAN dalam upaya memadamkan karhutla, opini negatif masyarakat global dan khususnya Asia Tenggara terhadap Indonesia akan terbentuk bahwa Indonesia tidak memiliki kemampuan mengatasi permasalahan domestiknya. Begitu pula bila Indonesia menerima bantuan yang tidak sesuai dengan kebutuhan dan terkesan menafikan upaya-upaya domestik yang sedang dilakukan ketika itu. Seperti yang dinyatakan oleh Sekretaris Kabinet Pramono Anung, pemerintah Indonesia tidak menghendaki upaya yang sedang dilakukan diklaim oleh asing di masa yang akan datang (Kompas, 2015). Tentunya hal tersebut dapat mencoreng citra Indonesia sebagai negara yang berdaulat. Kepentingan citra mendorong Indonesia menolak mengatasi karhutla dan kabut asap 2015 bersama-sama dengan negara ASEAN lainnya dengan mekanisme JER.

Sikap Indonesia sesuai dengan argumen Wang (2006) bahwa citra menjadi penting bagi negara dalam hubungan internasional. Reputasi negara akan dapat dilihat dengan indikator opini tentang negara tersebut yang diberikan oleh publik luar negeri. Mengelola reputasi nasional sudah menjadi bagian terintegral dalam politik luar negeri dan diplomasi (Wang, 2006). Dengan demikian, negara akan senantiasa menjaga reputasi 'baik' dalam berhubungan dengan aktor lain, termasuk dalam hal mengatasi masalah domestik.

\subsubsection{Kepentingan Ekonomi}


Indonesia merupakan salah satu produsen sekaligus eksportir kelapa sawit dan bubur kertas terbesar di dunia dan kedua industri tersebut merupakan sektor yang berkontribusi terhadap perekonomian nasional. Ekspansi perkebunan kelapa sawit dan hutan tanaman industri memberikan keuntungan ekonomi walaupun keduanya juga sering berpotensi menyebabkan kerusakan lingkungan.
Permintaan global dan domestik terhadap kelapa sawit dan bubur kertas menjadi determinan utama perluasan sektor perkebunan dan hutan tanaman industri di Indonesia.

Gabungan Asosiasi Pengusaha Kelapa Sawit Indonesia (GAPKI) dan Kementerian Pertanian telah mencatat produksi, ekspor dan luas area perkebunan kelapa sawit seperti di bawah ini:

Tabel 1.

Produksi, Ekspor dan Luas Perkebunan Kelapa Sawit di Indonesia 2008-2016

\begin{tabular}{|c|c|c|c|c|c|c|c|c|c|}
\hline & 2008 & 2009 & 2010 & 2011 & 2012 & 2013 & 2014 & 2015 & 2016 \\
\hline $\begin{array}{l}\text { Production } \\
\text { (million } \\
\text { tons) }\end{array}$ & 19.2 & 19.4 & 21.8 & 23.5 & 26.5 & 30.0 & 31.5 & 32.5 & 32.0 \\
\hline $\begin{array}{l}\text { Export } \\
\text { (million } \\
\text { tons) }\end{array}$ & 15.1 & 17.1 & 17.1 & 17.6 & 18.2 & 22.4 & 21.7 & 26.4 & 27.0 \\
\hline $\begin{array}{l}\text { Export } \\
\text { (in USD } \\
\text { billion) }\end{array}$ & 15.6 & 10.0 & 16.4 & 20.2 & 21.6 & 20.6 & 21.1 & 18.6 & 18.6 \\
\hline $\begin{array}{l}\text { Plantation } \\
\text { size (in } \\
\text { million ha) }\end{array}$ & n.a. & n.a. & n.a. & n.a. & 9.6 & 10.5 & 10.7 & 11.4 & 11.8 \\
\hline
\end{tabular}

Sumber: (Indonesia Investments, 2017a)

Kurang dari satu dekade, Indonesia telah mengalami peningkatan produksi, ekspor dan luas perkebunan kelapa sawit secara bersamaan. Pada tahun 2008, Indonesia menghasilkan 19,2 juta ton dan produksi meningkat sampai 32,5 juta ton pada 2015. Lebih lanjut GAPKI memperkiraakan produksi tersebut akan mencapai tidak kurang dari 40 juta ton mulai 2020 (Indonesia Investments, 2017a). Peningkatan produksi tidak hanya didorong oleh tujuan ekspor tapi juga konsumsi domestik di mana adanya peningkatan pertumbuhan populasi kelas menengah dan pengembangan program biodiesel oleh pemerintah Indonesia (Indonesia Investments, 2017a). Hanya pada tahun 2016, produksi kelapa sawit sedikit menurun. Ekspor mencapai 26,4 juta ton pada 2015 dan 27 juta ton pada
2016 masing-masing senilai USD 18,6 miliar dan sektor ini merupakan salah satu pendapatan devisa cukup besar bagi Indonesia. Industri kelapa sawit telah memberikan kontribusi terhadap GDP antara 1,5 dan 2,5 persen (Indonesia Investments, 2017a) selain menyediakan lapangan pekerjaaan bagi 8 juta penduduk khususnya di daerah pedesaan pada 2016 (Schleicher et al., 2019).

Industri kelapa sawit tak dapat dipisahkan oleh peran investasi swasta termasuk yang berasal dari luar negeri. Sebagian besar perkebunan kelapa sawit yaitu 52,88 persen merupakan Big Private Plantations (BPP); sedangkan 40,49 persen dimiliki oleh Smallholder Farmers (SF) dan 6,63 persen dimiliki oleh Big State-Owned Plantations (BSOP) (Indonesia Investments, 2017a). 
Perkebunan tersebut beroperasi di pulau Sumatera dan Kalimantan.

Sama halnya seperti industri kelapa sawit, industri bubur kertas telah memainkan peran penting dalam perekonomian Indonesia. Indonesia memberikan perhatian terhadap Industri tersebut karena adanya peningkatan global terhadap bubur dan kertas dan menargetkan peningkatan kapasitas produksi antara 7,93 juta ton sampai 10,53 juta ton per tahun (Indonesia Investments, 2017b). Konsesi diberikan kepada investor domestik dan asing. Sekitar 60 persen dari ouput bubur kertas diekspor ke luar negeri dan selebihnya untuk kebutuhan dometik (Indonesia Investments, 2017b). Pada 2017 industri bubur kertas memberikan kontribusi sebesar USD 5,8 miliar terhadap devisa nasional (Tempo, 2018). Industri tersebut dapat menyerap 126 ribu pekerja langsung dan 1,1 juta pekerja tak langsung (Indonesia Investments, 2017b). Pada 2018, industri bubur kertas memberikan kontribusi sebesar 1,3 persen terhadap GDP (Setiawati, 2018).

$$
\text { Satelit independen }
$$

memperkirakan keseluruhan lahan perkebunan kelapa sawit dan hutan tanaman industri mencapai 24 juta hektar, atau 12 persen dari total luas daratan Indonesia (Alisjahbana \& Busch, 2017). Namun, bertentangan dengan kontribusi yang diberikan, perusahaan-perusahaan yang bergerak di kedua sektor industri tersebut juga memberikan andil menyebabkan karhutla di Indonesia dengan menerapkan metode membakar (slash and burning) untuk membersihkan lahan di area konsesi mereka, termasuk perusahaan-perusahan Singapura dan Malaysia. Pemerintah Indonesia telah mengambil berbagai tindakan hukum terhadap pelaku kejahatan karhutla, namun kasus yang sama tetap terjadi setiap tahunnya. Lebih jauh Varkkey (2012b; 2013) mengungkapkan bahwa investor Malaysia dan Singapura menguasai lebih dari dua per tiga perkebunan kelapa sawit di Indonesia dan mereka terlindungi dengan adanya praktik patronase oleh otoritas Indonesia walaupun ada bukti keterlibatan perusahan tersebut menerapkan metode membakar lahan. Selain itu, frekuensi titik panas terbesar selalu berada pada area perkebunan kelapa sawit, hutan tanaman industri dan konsesi perkayuan (Purnomo et al., 2019; Sambodo, 2015).

Sesuai dengan AATHP, bila Indonesia meminta bantuan regional kepada ASEAN, pemerintah Indonesia memiliki tanggungjawab untuk menyediakan akses terhadap semua sumber daya kepada ASEAN dan pihakpihak yang membantu untuk mengatasi karhutla. Akses tersebut juga dapat berupa data berkaitan dengan perusahan nasional dan asing yang beroperasi di sektor perkebunan dan kehutanan di Indonesia. AATHP mendorong data sharing dan transparansi terhadap informasi kunci berkaitan kabut asap dan sumbersumbernya (Putraditama, 2014).

Bagi Indonesia, data tersebut merupakan hal yang sensitif karena berkaitan dengan proyeksi strategis nasional terhadap pertanian dan kehutanan. Sebagai institusi yang memfasilitasi dan mengkoordinasikan kerjasama dengan mekanisme JER, ASEAN Centre dapat meminta komitmen Indonesia atau membicarakan rekomendasi berupa sanksi mulai dari bentuk denda sampai pada pencabutan konsesi perusahaanperusahaan yang menerapkan metode membakar dalam membersihkan lahan mereka. Sanksi dan pencabutan konsesi dapat berdampak pada perekonomian nasional dan penerimaan devisa. Tidak hanya merugikan kepentingan ekonomi, transfer data kepada ASEAN dapat mengancam kedaulatan ekonomi karena organisai regional tersebut dan negaranegara anggota lainnya dapat melakukan intervensi dalam pembuatan keputusan strategis Indonesia.

Industri kelapa sawit dan bubur kertas merupakan program prioritas karena kontribusi yang diberikan terhadap 
perekonomian Indonesia. Kedua industri tersebut telah membantu pemerintah Indonesia dalam mewujudkan pertumbuhan ekonomi dan distribusi pendapatan negara. Selain memberikan kontribusi yang signifikan terhadap sektor pertanian, industri kelapa sawit juga sering dipromosikan sebagai kontributor utama dalam upaya mengurangi kemiskinan dan wewujudkan kemandirian pangan dan energi oleh pemerintah (Pirker et al., 2016). Sementara itu, industri bubur kertas memberikan kontribusi yang signifikan pula terhadap sektor kehutanan nasional. Dengan demikian, Indonesia akan menjaga kedua sektor tersebut tetap beroperasi tanpa gangguan ataupun intervensi asing.

Dari pertimbangan ekonomi, penerapan mekanisme JER yang ada dalam AATHP dapat mengancam pertumbuhan dan program pengembangan ekonomi di sektor pertanian dan kehutanaan, begitu juga dengan kebutuhan domestik. Sikap penolakan Indonesia dalam hal ini sesuai dengan argumen $\mathrm{Wu}$ (2017) bahwa perkembangan ekonomi menjadi salah satu kepentingan spesifik yang diturunkan dari beberapa tujuan utama yang dikejar oleh pemerintah negara. Dengan mempertimbangkan kepentingan ekonomi, Indonesia menolak menggunakan JER yang terdapat pada AATHP.

\subsubsection{Kepentingan Politik}

AATHP memungkinkan Indonesia dan negara anggota ASEAN lainnya menghukum perusahaan yang berasal dari salah satu negara ASEAN yang membakar hutan dan lahan di Indonesia, khususnya bila menggunakan mekanisme JER. Namun, Indonesia menjadikan isu kabut asap dan AATHP untuk menaikkan bargaining position-nya untuk menekan Singapura agar kembali membicarakan penjanjian ekstradisi yang selama ini dihindari oleh negara tersebut. Singapura termasuk negara yang sangat berkepentingan dalam penanggulangan bencana karhutla dan kabut asap karena selalu menjadi korban hampir setiap tahun.

Keinginan Indonesia mengadakan perjanjian ekstradisi dengan Singapura disebabkan oleh semakin meningkatnya tindak pidana korupsi dan pencucian uang serta capital flight oleh pemangkir pajak. Saat ini Singapura menjadi salah satu negara terdekat yang menjadi sasaran bagi pejabat, politisi dan pengusaha Indonesia yang terlibat tindak korupsi dan pencucian uang serta pemangkir pajak. Selain alasan kedekatan geografis, Singapura dijadikan tempat persembunyian karena tidak adanya perjanjian ektradisi antara kedua negara tersebut. Dalam kasus korupsi, laporan Indonesian Corruption Watch (ICW) menyebutkan telah ada sekitar 43 orang yang terlibat kasus korupsi melarikan diri ke Singapura sejak tahun 2001 (Ismail \& Nggilu, 2019). Dengan tidak adanya perjanjian ekstradisi, Singapura juga tidak memiliki kewajiban terhadap Indonesia untuk mengembalikan asset illegal yang disimpan di sana. Menkeu Bambang Brojonegoro dalam sebuah wawancara mengatakan jumlah asset tersebut bisa mencapai USD 300 miliar (Desker, 2015).

Hubungan diplomatik Indonesia dan Singapura telah mengalami pasang surut. Kedua negara telah bersitegang dalam berbagai isu mulai dari kabut asap, ekspor pasir dan perjanjian ekstradisi (Laksmana, 2012). Singapura pernah membawa masalah kabut asap akibat karhutla dalam sidang umum PBB pada 20 Oktober 2006 dan mendapatkan kecaman dari Indonesia karena dianggap menciptakan preseden buruk bagi Indonesia (Suryani, 2012). Pada tahun 2007, Indonesia mengeluarkan kebijakan melarang ekspor pasir ke Singapura setelah mempertimbangkan degradasi lingkungan yang disebabkan oleh penggalian pasir di sekitar Kepulauan Riau. Indonesia sebelumnya merupakan salah satu pemasok utama pasir untuk proyek-proyek reklamasi daratan Singapura. 
Reklamasi pantai telah menyebabkan daratan Singapura maju sejauh 12 mil menjorok ke wilayah perairan Indonesia, bergeser dari original base line perjanjian perbatasan IndonesiaSingapura pada 1973 (Wicaksono, 2016) dan berpotensi menjadi konflik delimitasi perbatasan kedua negara di masa depan (Yudha AR, 2007). Menanggapi kebijakan tersebut, Singapura meminta Indonesia tidak hanya peduli pada kerusakan lingkungannya, tapi juga masalah kabut asap akibat bencana karhutla yang terjadi di Indonesia. Singapura juga menyatakan keberatannya bila kebijakan pelarangan ekspor pasir dijadikan alat untuk menekan negara tersebut agar menyetujui perjanjian ekstradisi dengan Indonesia.

Hubungan bilateral Indonesia dan Singapura kembali membaik ditandai dengan pertemuan antara kedua negara dalam penandatanganan $\mathrm{MoU}$ perjanjian ekstradisi, dua bulan setelah larangan ekspor pasir oleh Indonesia tepatnya pada 27 April 2007. Perjanjian tersebut berisi 31 jenis kejahatan, termasuk korupsi (Ismail \& Nggilu, 2019). Namun, Singapura menambah syarat agar kesepakatan ekstradisi tercapai berupa Defense Cooperation Agreement (DCA) yang memungkinkan Singapura menggunakan wilayah Indonesia sebagai tempat latihan perang angkatan bersenjatanya termasuk melibatkan pihak ketiga (Milia, Kurniawan \& Poespitohadi, 2018). Barter DCA dengan perjanjian ekstradisi merupakan strategi Singapura menggagalkan upaya Indonesia mewujudkan perjanjian ekstradisi karena Indonesia tidak akan menyetujui perjanjian DCA yang merugikan kedaulatannya dan memberikan keuntungan yang lebih besar kepada Singapura. Dengan ditolaknya perjanjian DCA oleh DPR RI, maka perjanjian ekstradisi antara Indonesia dan Singapura tidak dapat dilanjutkan.

Pada 2014 hubungan Indonesia dan Singapura kembali menegang setelah parlemen Singapura mengesahkan Transbondary Haze Pollution Act (THPA).
THPA memungkinkan Singapura mengadili dan menghukum individu ataupun perusahaan di luar yurisdiksinya, termasuk pihak-pihak yang terlibat dalam menyebabkan karhutla di Indonesia. Langkah Singapura tersebut dianggap tidak menghormati kedaulatan dan merendahkan yurusdiksi hukum Indonesia karena otoritas hukum yang dibuat oleh pemerintah berdaulat hanya berlaku bagi warga negaranya. Singapura merespon Indonesia dengan mengangkat isu karhutla di forum ASEAN, sebaliknya Indonesia merespon dengan mengangkat isu perjanjian ektradisi yang sampai saat ini enggan disepakati oleh Singapura.

Singapura menolak meratifikasi perjanjian ekstradisi dengan Indonesia selama Indonesia masih menolak meratifikasi DCA. Sebaliknya, Indonesia menjadikan bencana kabut asap 2015 untuk melihat respon Singapura. Bila Singapura menderita kerugian dari kabut asap akibat karhutla yang terjadi di Indonesia, maka Indonesia juga dirugikan selama Singapura masih menjadi tempat yang aman bagi kriminal Indonesia walaupun Singapura memiliki reputasi sebagai salah satu negara dengan tingkat persepsi korupsi terendah ataupun clean government tertinggi di dunia. Bagi Indonesia, menyepakati perjanjian ekstradisi akan memberikan manfaat bagi kepentingan nasional kedua negara (Juwana, 2007).

Tarik-menarik kepentingan politik menjadi lumrah dalam hubungan antar negara. Negara menggunakan satu isu untuk menaikkan posisinya terhadap isu lain. Peneliti melihat penolakan Indonesia untuk menerapkan mekanisme JER sebagai strategi Indonesia agar dapat menjadikan isu kabut asap sebagai alat menekan balik pemerintah Singapura dalam urusan perjanjian ekstradisi karena negara tersebut yang paling berkeinginan agar Indonesia serius mengatasi bencana karhutla, termasuk optimalisasi peran ASEAN dan AATHP. Dengan demikian, penolakan Indonesia menggunakan JER 
juga didorong oleh kepentingan politik terhadap Singapura.

\subsection{Kebijakan Indonesia Menolak Menggunakan Mekanisme JER}

\subsubsection{Pernyataan Menolak Menggunakan Mekanisme JER}

Indonesia menolak menggunakan mekanisme JER dalam menangani bencana karhutla 2015 sehingga ASEAN tidak dapat berperan lebih besar seperti yang tertuang dalam AATHP. ASEAN hanya dapat memberikan bantuan jika Indonesia meminta setelah menyatakan status darurat nasional. Sebaliknya, Indonesia menganggap rumitnya mekanisme permintaan bantuan dalam AATHP untuk mengatasi bencana tersebut menjadi penguat keputusan Indonesia untuk tidak menggunakan skema JER.

Pasal 12 dalam AATHP yang mengatur mengenai mekanisme JER, sebagai berikut:

"(1) If a Party needs assistance in the event of land and/or forest fires or haze pollution arising from such fires within its territory, it may request such assistance from any other Party, directly or through the ASEAN Centre, or, where appropriate, from other States or international organisations; (2) Assistance can only be employed at the request of and with the consent of the requesting Party, or, when offered by another Party or Parties, with the consent of the receiving Party;........" (AATHP, n.d).

Dari gambaran di atas, bantuan hanya dapat diberikan atas permohonan dari dan dengan persetujuan pihak pemohon atau bila ditawarkan oleh pihak lain dengan persetujuan dari pihak penerima bantuan. Selain karena rumitnya mekanisme JER tersebut, mekanisme pengambilan keputusan ASEAN harus melalui konsensus. Sesuai dengan mekanisme tersebut, Indonesia terlebih dahulu harus meminta bantuan dengan surat permohonan dalam menanggulangi karhutla, kemudian pertemuan dengan seluruh anggota ASEAN baru dapat dilaksanakan. Lalu dari pertemuan tersebut diambil keputusan untuk menentukan langkah yang akan ditempuh untuk memberikan bantuan kepada Indonesia dalam menanggulangi karhutla dan kabut asap. Prosedur permintaan bantuan dan pemberitahuan kepada seluruh negara anggota ASEAN membuat Indonesia enggan untuk memilih mekanisme JER.

Pemerintah Indonesia sering menyampaikan kepada publik bahwa Indonesia mampu dalam mengatasi bencana karhutla sehingga tidak membutuhkan bantuan ASEAN ataupun negara-negara anggotanya. Misalnya seperti yang disampaikan oleh Juru Bicara Kemlu Armanatha Nasir, "Mereka (Singapura) memang menawarkan bantuan dengan sistem yang mereka punya, tapi Indonesia masih bisa" (Tempo, 2015a). Begitu juga Menteri Lingkungan Hidup dan Kehutanan Siti Nurbaya dalam merespon tawaran pesawat C-130 dan pesawat Chinooks untuk membuat hujan buatan: "Pemerintah menolak bantuan tersebut dengan alasan masih sanggup menanganinya" (Tempo, 2015b).

Pernyataan 'percaya diri' sudah lazim disampaikan Indonesia dalam berbagai peristiwa karhutla di wilayahnya. Sedangkan Pernyataan Indonesia yang meragukan efektifitas AATHP dan keengganan meminta bantuan kepada ASEAN merupakan wujud kebijakan menolak penanganan bencana dengan mekanisme JER. Pernyaatan ini kemudian diikuti oleh keengganan Indonesia menerima bantuan yang datang dari khususnya negara-negara ASEAN. Indonesia lebih memilih mengandalkan kemampuan domestik walaupun akhirnya menerima bantuan asing secara selektif 
melalui kerjasama bilateral ketika situasi bencana semakin sulit untuk diatasi.

\subsubsection{Penanganan Karhutla dan Kabut Asap Secara Nasional}

Keinginan Indonesia untuk menyelesaikan masalah bencana karhutla tanpa keterlibatan ASEAN sudah tersirat di awal-awal pemerintahan Presiden Joko Widodo ketika ia menyatakan akan menyelesaikan masalah tersebut dalam waktu tiga tahun (Varkkey, 2017). Pemerintah Indonesia menyanggah kritikan dari negara-negara anggota ASEAN yang menyatakan ketidakmampuan Indonesia menangani bencana kabut asap. Indonesia beralasan lambatnya pemadaman karhutla dikarenakan faktor cuaca. Dalam upaya penanganan bencana karhutla dan kabut asap 2015, pemerintah pusat bekerja sama dengan pemerintah daerah baik dengan sentralisasi ataupun desentralisasi kebijakan serta melibatkan masyarakat tempatan. Indonesia tidak menyatakan status tanggap darurat nasional, namun megizinkan beberapa propinsi menyatakan status siaga darurat maupun tanggap dururat daerah (Alfajri \& Luerdi, 2016).

Salah satu langkah penanggulangan karhutla yang dilakukan adalah penggunaan bahan kimia sebanyak 40 ton untuk memadamkan karhutla, khususnya di wilayah Sumatera dan Kalimantan dengan mengerahkan lebih dari 22 ribu aparat termasuk TNI dan Polri (VOA Indonesia, 2015). Selain penggunaan bahan kimia dan water bombing yang diikuti upaya pemadaman di darat, modifikasi cuaca untuk hujan buatan juga dilakukan. Indonesia telah mengerahkan 25 unit pesawat untuk memadamkan api dan menyemai awan untuk membuat hujan (DW Indonesia, 2015a).

Sejak awal Indonesia telah berupaya untuk menangani karhutla 2015. Namun, jarak pandang yang buruk, awan yang tidak cukup untuk disemai dan keterbatasan air akibat faktor cuaca menyulitkan proses pemadaman. Sulitnya penanganan karhutla dan dampak dari kabut asap yang semakin buruk serta tuntutan dari berbagai elemen domestik mendorong Indonesia bersedia menerima bantuan negara asing yang dituangkan dalam kerjasama bilateral agar mempercepat pemadaman karena upayaupaya domestik membutuhkan waktu yang lebih lama dan tidak menunjukkan keberhasilan yang signifikan.

Preferensi Indonesia dalam mengatasi karhutla secara domestik merupakan upaya untuk menghindari intervensi asing dan diperkuat oleh sentimen nasionalisme elit domestik. Dengan demikian, Indonesia dapat secara bebas menentukan strategi domestik dalam penanganan bencana tersebut demi menjaga kepentingan nasional. Dengan melihat preferensi tersebut, Indonesia merupakan pendukung utama norma noninterference di kawasan bila terkait isu lingkungan (Varkkey, 2009).

\subsubsection{Penangangan Karhutla dan Kabut Asap Secara Bilateral}

Dalam mengatasi karhutla 2015, Indonesia akhirnya menerima bantuan dari negara-negara asing. Enam negara yang memberikan bantuan antara lain Singapura, Malaysia, Australia, Cina, Jepang dan Rusia melalui kerjasama bilateral. Sebelumnya, Indonesia sempat menolak beberapa kali tawaran Singapura karena ketidaksesuaian antara bantuan yang ditawarkan dengan kebutuhan di lapangan. Dalam menerima bantuan asing, Indonesia melakukannya secara selektif agar benar-benar efektif pada upaya pemadaman karhutla di tengah-tengah situasi cuaca yang ekstrim. Bantuan yang paling krusial adalah alat pengangkut air dengan kapasitas besar yang akan dikonsentrasikan di Sumatera (DW Indonesia, 2015b).

Singapura telah mengirimkan bantuan berupa pesawat Chinook pengangkut air bermuatan 5 ribu liter, 
Malaysia telah mengirimkan bantuan berupa satu unit pesawat jenis bombardir 415 MP dengan kapasitas 6 ribu liter, Australia memberikan bantuan berupa satu unit pesawat Hercules dengan kapasitas 15 ribu liter, Jepang memberikan bantuan berupa bahan kimia untuk mempercepat proses pemadaman beserta tenaga ahlinya, dan Rusia mengirimkan bantuan berupa dua unit pesawat amfibi BE-200 yang bisa mengangkut 12 ribu liter (Winnetnews, 2015). Kerjasama yang dilakukan oleh Indonesia dengan negara-negara tersebut berlangsung selama lebih kurang dua minggu.

Mekanisme penanganan bencana karhutla bilateral lebih disukai oleh Indonesia ketimbang secara multilateral dengan mekanisme JER yang ada pada AATHP. Bantuan dari berbagai negara asing ternyata dibutuhkan oleh Indonesia mengingat minimnya peralatan khususnya pesawat yang mengangkut air bila dibandingkan dengan luas lahan yang dilanda kebakaran. Pilihan penyelesaian bencana 2015 secara bilateral juga sebagai indikator Indonesia pada dasarnya tidak menginginkan mekanisme JER yang akan melibatkan peran ASEAN secara lebih besar.

Inisiatif bilateral dalam mengahadapi bencana karhutla sudah menjadi institusi dalam politik luar negeri Indonesia baik dalam hal pencegahan maupun mitigasi. Artinya, bila melihat peristiwa-peristiwa karhutla di masa lalu, kerjasama bilateral dianggap lebih efektif dan tidak menciderai kedaulatan negara atau kepentingan nasional, serta selaras dengan prinsip-prinsip yang dipegang oleh ASEAN. Singapura, misalnya, sebagai salah satu pihak yang dirugikan menyadari keengganan Indonesia menyelesaikan karhutla secara multilateral sehingga terpaksa memilih mekanisme two-track engagement antar kedua negara yang melahirkan Singapore-Jambi Master Plan (Varkkey, 2011).

\section{Kesimpulan}

Tulisan ini ingin menegaskan bahwa Indonesia memiliki pilihan skema JER dalam merespon bencana karhutla 2015 secara multilateral sebagai 'insentif' dari ratifikasi AATHP. Namun, berbeda dengan optimisme Jerger Jr (2014) terhadap peran besar Indonesia dan ASEAN, ratifikasi oleh Indonesia tidak serta merta menjadi game changer bagi ASEAN untuk bebas dari polusi kabut asap (Heilmann, 2015). Herley dan Lee (2020) menilai ratifikasi AATHP oleh Indonesia sekedar gestur simbolik 'niat baik' terhadap masalah lingkungan di kawasan. Dalam merespon bencana tersebut, kebijakan menolak menggunakan mekanisme JER yang ada pada AATHP dianggap sebagai keputusan yang terbaik bagi Indonesia demi mempertahankan kepentingan nasional yang jauh lebih penting ketimbang komitmen terhadap AATHP yang telah diratifikasi setahun sebelumnya. Kepentingan nasional tersebut tidak hanya berdimensi ekonomi, tapi juga mempertahankan reputasi negara dan meningkatkan daya tawar politik. Prinsip-prinsip yang dipegang oleh ASEAN juga merupakan celah bagi Indonesia untuk menghindari skema JER sehingga upaya nasional dan bilateral masih menjadi prioritas. Sikap ini akan tetap berlanjut di masa yang akan datang selagi tidak ada forces yang efektif menekan Indonesia.

Tulisan ini dapat menggambarkan bargaining position Indonesia di tengahtengah ekspektasi aktor regional terhadap perilakunya terkait masalah karhutla dan kabut asap. Walaupun dapat menggambarkan titik kelemahan dari AATHP dan preferensi kebijakan Indonesia, tulisan ini masih menyisakan celah berupa kekosongan penjelasan tentang dinamika aktor-aktor domestik dalam mempengaruhi proses pembuatan keputusan terkait penyelesaian bencana karhutla dan kabut asap paska ratifikasi AATHP. Penelitian di masa yang akan datang diharapkan mampu mengisi kekosongan tersebut. Secara umum, 
tulisan ini bermanfaat bagi peneliti dan penstudi regionalisme dan politik lingkungan di Asia Tenggara.

\section{Tentang Penulis}

Luerdi, S.IP., M.Si merupakan dosen pada Program Studi Ilmu Hubungan Internasional Universitas Abdurrab.

Melly Wulandari, S.IP merupakan alumni Program Studi Ilmu Hubungan Internasional Universitas Abdurrab.

\section{Ucapan Terima Kasih}

Tim peneliti mengucapkan terima kasih kepada seluruh kolega pada Prodi Ilmu Hubungan Internasional Universitas Abdurrab yang telah memberikan masukan dalam penyusunan naskah ini.

\section{Referensi}

Ahmadi, S. (2012). Prinsip NonInterference ASEAN dan Problem Efektivitas Asean Agreement on Transboundary Haze Pollution. Jurnal Hubungan Internasional, 1(2), 187-195.

Alfajri, A., \& Luerdi, L. (2016). Riau Government's Policies to Realize the AATHP's Goals (2015-2016). Prosiding Seminar Hasil Penelitian Universitas Abdurrab, 187-198.

Alfajri, A., Setiawan, A., \& Wahyudi, H. (2019). Civil Society Organizations (CSOs) Perspective and Haze-Free ASEAN 2020: Evidences from Riau. The Malaysian Journal of International Relations, 7(1), 21-56.

Alfajri, A., Setiawan, A., \& Wahyudi, H. (2021). The Post - ASEAN's HazeFree Roadmap 2020 and Implementation of Precautionary Principle in Indonesia's Environmental Diplomacy: Riau's Perspective. Berumpun: International Journal of Social, Politics, and Humanities, 4(1), 1539.
Alisjahbana, A.S., \& Busch, J.M. (2017). Forestry, Forest Fires and Climate Change in Indonesia. Bulletin of Indonesian Economic Studies, 53(2), 111-136.

Anggarwal, V.K., \& Chow, J.T. (2010). The Perils of Consensus: How ASEAN's Meta-Regime Undermines Economic and Environmental Cooperation. Review of International Political Economy, 17(2), 262-290.

Apriwan, A. (2012). The Securitization of Environmental Issues in Southeast Asia. Andalas Journal of International Studies, 1(1), 20-35.

ASEAN Agreement on Transboundary Haze Pollution (AATHP). (n.d). ASEAN Secretariat. Diperoleh dari: http://haze.asean.org/?wpfb_dl=32

BBC Indonesia. (2016). "Dapatkah Kebakaran Hutan di Indonesia Diakhiri?" 15 Maret. Diperoleh dari: https://www.bbc.com/indonesia/berit a_indonesia/2016/03/160314_indone sia_kebakaran_hutan_2016

Burki, T.K. (2017). The Pressing Problem of Indonesia's Forest Fires. The Lancet, 5(9), 685-686.

Dauvergne, P. (1998). The Political Economy of Indonesia's 1997 Forest Fires. Australian Journal of International Affairs, 52(1), 13-17.

Desker, B. (2015). Challenging Times in Singapore-Indonesia Relations, RIS Commentary, 14 October. Singapore: Nanyang Technological University.

DW Indonesia. (2015a). Indonesia Kembali Tolak Bantuan Singapura. 1 Oktober. Diperoleh dari: https://www.dw.com/id/indonesiakembali-tolak-bantuan-singapura/a18752664

DW Indonesia. (2015b). Bantuan Internasional Tiba di Indonesia. 12 Oktober. Diperoleh dari: https://www.dw.com/id/bantuaninternasional-tiba-di-indonesia/a$\underline{18776204}$ 
Edwards, S.A., \& Heiduk, F. (2015). Hazy Days: Forest Fires and the Politics of Environmental Security in Indonesia. Journal of Current Southeast Asian Affairs, 34(3), 65-94.

Fathun, L.M. (2016). Bencana Hutan dalam Hubungan Internasional. Andalas Journal of International Studies, 5(1), 84-107.

Febriyani, N. (2019). Analisis Kebijakan Indonesia Terkait Penundaan dalam Meratifikasi ASEAN Agreement on Transboundary Haze Pollution (AATHP) Tahun 2002-2014. Jurnal Studi Diplomasi dan Keamanan, 2(2), 73-87.

Ghani, F.A., et al. (2017). Review on ASEAN Transboundary Haze Pollution Agreement 2002: Problems and Solutions. Journal of Humanities, Language, Culture and Business, 1(1), 153-161.

Glauber, A.J., et al. (2016). Kerugian dari Kebakaran Hutan: Analisa Dampak Ekonomi dari Krisis Kebakaran tahun 2015, Laporan Pengetahuan Lanskap Berkelanjutan Indonesia, Februari. Jakarta: World Bank.

Gunardi, G., Masman, R.R., \& Martono, M. (2017). Legal Aspects, Economic and Aircraft's Water Bombing Related to Forest Fires in Indonesia. International Journal of Business and Management Invention, 6(3), 718.

Gunawan, Y. (2014). Transboundary Haze Pollution in the Perspective of International Law of State Responsibility. Jurnal Media Hukum, 21(2), 170-180.

Gunawan, Y., \& Yogar, H.N.A. (2019). The Responsibility of Indonesia towards Transboundary Haze Pollution After the AATHP Ratification. The European Proceedings of Social and Behavioural Sciences, 206-217.

Heilmann, D. (2015). After Indonesia's Ratification: The ASEAN Agreement on Transboundary Haze
Pollution and Its Effectiveness As a Regional Environmental Governance Tool. Journal of Current Southeast Asian Affairs, 34(3), 95-121.

Hurley, A., \& Lee, T. (2020). Delayed Ratification in Environmental Regimes: Indonesia's Ratification of the ASEAN Agreement on Transboundary Haze Pollution. The Pacific Review, 1-30.

Idrus, M. (2009). Metode Penelitian Ilmu Sosial: Pendekatan Kualitatif dan Kuantitatif, Edisi Kedua. Jakarta: Penerbit Erlangga.

Indonesia Investments. (2017a). Indonesian Palm Oil Production and Export. Diperoleh dari: https://www.indonesiainvestments.com/business/commodit ies/palm-oil/item 166

Indonesia Investments. (2017b). Pulp and Paper Industry Indonesia: Challenges and Opportunities. Diperoleh dari: https://www.indonesiainvestments.com/news/todaysheadlines/pulp-and-paper-industryindonesia-challenges-andopportunities/item 7738

Ismail, D.E., \& Nggilu, N.M. (2019). The Urgency of Indonesia-Singapore's Extradition Agreement in the Corruption Law Enforcement. Proceedings of the 3rd International Conference on Globalization of Law and Local Wisdom, 358, 157-160.

Jakarta Globe. (2015). Haze Is Gone but Answers Remain Thin. 14 December. Diperoleh dari https://jakartaglobe.id/news/hazegone-answers-remain-thin/

Jerger Jr, D.B. (2014). Indonesia's Role in Realizing the Goals of ASEAN's Agreement on Transboundary Haze Pollution. Sustainable Development Law and Policy, 14(1), 35-45.

Juwana, H. (2007). Is the Extradition Treaty in the Interest of Singapore. Jakarta Post, 8 Agustus, hal.5. 
Kementerian Kesehatan RI. (2015). Masalah Kesehatan Akibat Kabut Asap Kebakaran Hutan dan Lahan Tahun 2015. Jakarta: Pusat Data dan Informasi Kementerian Kesehatan RI.

Kompas. (2015). Terima Bantuan Asing, Pemerintah Akui Kebakaran Hutan Sulit Diatasi. 12 Oktober. Diperoleh dari:

https://nasional.kompas.com $/ \mathrm{read} / 20$ 15/10/12/13085721/Terima.Bantuan. Asing.Pemerintah.Akui.Kebakaran. Hutan.Sulit.Diatasi

$\mathrm{Ku}$ Yusof, K.M.K., et al. (2017). An Overview of Transboundary Haze Studies: The Underlying Causes and Regional Disputes on Southeast Asia Region. Malaysian Journal of Fundamental and Applied Sciences, 13(4), 747-753.

Laksmana, E.A. (2012). Regional Order by Other Means? Examining the Rise of Defense Diplomacy in Southeast Asia. Asian Security, 8(3), 2012, 251-270.

Lerche, C.O., \& Said, A.A. (1995). Concepts of International Politics, 4th Edition. Englewood Cliffs: Prentice Halls.

Milia, J., Kurniawan, Y., \& Poespitohadi, W. (2018). Analysis of Defense Cooperation Agreement between Indonesia and Singapore in 20072017 through Defense Diplomacy Goal Variable. Jurnal Pertahanan, 4(2), 104-119.

Pirker, J., et al. (2016). What Are the Limits to Oil Palm Expansion? Global Environmental Change, 40, 73-81.

Purnomo, H., et al. (2019). Forest and Land Fires, Toxic Haze and Local Politics in Indonesia. International Forestry Review, 21(4), 1-15.

Purwendah, E.K., \& Mangku, D.G.S. (2018). The Implementation of Agreement on Transboundary Haze Pollution in the Southeast Asia Region for ASEAN Member
Countries. International Journal of Business, Economics and Law, 17(4), 8-14.

Putraditama, A. (2014). Law Enforcement 'Essential' to Indonesia's Fight against Haze. Wawancara oleh DW, 23 September. Diperoleh dari: https://www.dw.com/en/lawenforcement-essential-to-indonesiasfight-against-haze/a-17948828

Sambodo, M.T. (2015). Indonesia Has Ratified the Asean Agreement on Transboundary Haze Pollution: Will the Haze Disappear? Review of Indonesian Economic and Business Studies, 6(1), 1-28.

Sari, S., \& Nirmala, N.P. (2019). Kerjasama Indonesia - Uni Eropa Dalam Mengoptimalkan Implementasi Reducing Emissions From Deforestation And Forest Degradation (Redd+): Studi Kasus Hutan Ulu Masen Aceh Tahun 20132017. Dinamika Global: Jurnal Ilmu Hubungan Internasional, 4(2), 249268.

Sarmiasih, M., \& Pratama, P.Y. (2019). The Problematics Mitigation of Forest and Land Fire District (Kerhutla) in Policy Perspective (A Case Study: Kalimantan and Sumatra in Period 2015-2019). Journal of Governance and Public Policy, 6(3), 270-292.

Schleicher, T., et al. (2019). Production of Palm Oil in Indonesia: CountryFocused Commodity Analysis in the Context of the Bio-Macht Project, Final Report. Freiburg: Oeko-Institut e.V.

Setyawati, A. (2018). Analysis: Pulp, Paper Industry Remains Strong Despite Challenges. 19 September. Diperoleh dari: https://www.thejakartapost.com/new s/2018/09/19/analysis-pulp-paperindustry-remains-strong-despitechallenges.html

Shidiq, M.A. (2016). Alasan Indonesia Meratifikasi ASEAN Agreement on 
Transboundary Haze Pollution (AATHP) dalam Penanganan Kabut Asap Lintas Batas. Global and Policy: Journal of International Relations, 4(1), 1-22.

Sipongi. (2015). Rekapitulasi Luas Kebakaran Hutan dan Lahan (Ha) Per Provinsi di Indonesia Tahun 2015-2020. Diperoleh dari: http://sipongi.menlhk.go.id/hotspot/l uas_kebakaran

Suartini, N.P.G., Sushanti, S., \& Priadarsini, N.W.R. (2018). Peran ASEAN dalam Mempengaruhi Indonesia untuk Meratifikasi ASEAN Agreement on Transboundary Haze Pollution (AATHP). Jurnal Hubungan Internasional, 1(2), 1-14.

Suryani, A.S. (2012). Penanganan Asap Kabut Akibat Kebakaran Hutan di Wilayah Perbatasan Indonesia. Jurnal Aspirasi, 3(1), 59-75.

Tay, S., Chen, L.C., \& Yi, L.X. (2016). Southeast Asia's Burning Issue: From the 2015 Haze Crisis to A More Robust System, Policy Brief, April. Singapore: Singapore Institute of International Affairs (SIIA).

Tempo. (2015a). Kebakaran Hutan Kian Meluas, Indonesia Tolak Bantuan Asing. 17 September. Diperoleh dari:

https://nasional.tempo.co/read/70152

5/kebakaran-hutan-kian-meluas-

indonesia-tolak-bantuan-

asing/full\&view $=$ ok

Tempo. (2015b). Alasan Jokowi Tolak Bantuan Negara Lain Padamkan Kebakaran. 7 Oktober. Diperoleh dari:

https://nasional.tempo.co/read/70730

3/alasan-jokowi-tolak-bantuan-

negara-lain-padamkan-

kebakaran/full\&view $=$ ok

Tempo. (2018). Development of Pulp and Paper Industry Becomes Priority. 12 November. Diperoleh dari: https://en.tempo.co/read/923347/dev elopment-of-pulp-and-paper- industry-becomes-priority

Varkkey, H.M. (2009). Indonesian Perspectives on Managing the Asean Haze. Jurnal Sarjana, 24(1), 83-101.

Varkkey, H.M. (2011). Addressing Transboundary Haze Through ASEAN: Singapore's Normative Constraints. Journal of International Studies, 7, 83-101.

Varkkey, H,M. (2012a). The ASEAN Way and Haze Mitigation Efforts. Journal of International Studies, 8, 77-97.

Varkkey, H,M. (2012b). Patronage Politics as A Driver of Economic Regionalisation: The Indonesian Oil Palm Sector and Transboundary Haze. Asia Pacific Viewpoint, 53(3), 314-329.

Varkkey, H,M. (2013). Malaysian Investors in the Indonesian Oil Palm Plantation Sector: Home State Facilitation and Transboundary Haze. Asia Pacific Business Review, 19(3), 381-401.

Varkkey, H,M. (2017). In 3 Years We Would Have Solved This: Jokowi, ASEAN and Transboundary Haze. Jurnal Studi Pemerintahan, 8(3), 277-295.

VOA Indonesia. (2015). BNPB Akan Gunakan Bahan Kimia untuk Atasi Kebakaran Hutan." 6 Oktober. Diperoleh dari: https://www.voaindonesia.com/a/bn pb-akan-gunakan-bahan-kimiauntuk-atasi-kebakaranhutan/2993276.html

Wang, J. (2006). Managing National Reputation and International Relations in the Global Era: Public Diplomacy Revisited. Public Relations Review, 32, 91-96.

Wicaksono, A. (2016). Mengatur Perbatasan Antar Negara Pasca Reklamasi Singapura: Integrasi Pengelolaan Aspek Ruang di Kepulauan Riau. Jejaring Administrasi Publik, 8(1), 867-880.

Winnetnews. (2015). Uluran Tangan Negara-Negara Sahabat untuk 
Padamkan Api di Hutan Indonesia. 12 Oktober. Diperoleh dari: https://www.winnetnews.com/post/u luran-tangan-negara-negara-sahabatuntuk-padamkan-api-di-hutanindonesia

Wu, C.C.H. (2017). Understanding the Structures and Contents of National Interests: An Analysis of Structural Equation Modeling. The Korean Journal of International Studies, 15(3), 391-420.

Yani, Y.M., \& Robertua, V. (2018). Environmental Studies of English
School: Case Study of Forest Fires in Indonesia and Transboundary Haze in Southeast Asia. Journal of ASEAN Studies, 6(1), 117-135.

Yudha AR, W. (2007). Reklamasi Singapura sebagai Potensi Konflik Delimitasi Perbatasan Wilayah Indonesia-Singapura. Global dan Strategis, 1(2), 120-137.

Zulaeha, M. (2016). Mengatasi Kabut Asap Melalui Mekanisme Citizen Lawsuit. Jurnal Hukum Lingkungan, 3(1), 87-106. 